IRA-International Journal of Education \& Multidisciplinary Studies

ISSN 2455-2526; Vol.04, Issue 01 (2016)

Institute of Research Advances

http://research-advances.org/index.php/IJEMS

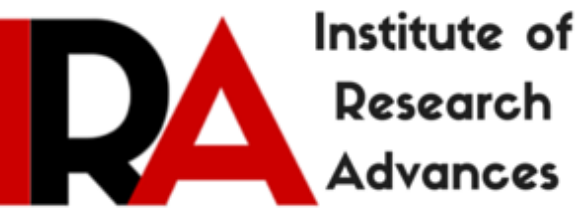

\title{
Effectiveness of Metacognitive Strategies through Reading Comprehension of Tertiary Level Leaner's of English
}

\author{
Dr. S. Diravidamani \\ Assistant Professor \\ Department of English \\ Periyar University College of Arts \& Science \\ Mettur Dam - 636401, Salem, India.
}

DOI: http://dx.doi.org/10.21013/jems.v4.n1.p19

\section{How to cite this paper:}

Diravidamani, S. (2016). Effectiveness of Metacognitive Strategies through Reading Comprehension of Tertiary Level Leaner's of English. IRA International Journal of Education and Multidisciplinary Studies (ISSN 2455-2526), 4(1).

doi:http://dx.doi.org/10.21013/jems.v4.n1.p19

(C) Institute of Research Advances

\section{(cc) BY-NC}

This works is licensed under a Creative Commons Attribution-Non Commercial 4.0 International License subject to proper citation to the publication source of the work.

Disclaimer: The scholarly papers as reviewed and published by the Institute of Research Advances (IRA) are the views and opinions of their respective authors and are not the views or opinions of the IRA. The IRA disclaims of any harm or loss caused due to the published content to any party. 


\section{Introduction}

Reading is the basic foundation on which academic skills of an individual are built. Reading is a fundamental skill to acquire information. To enhance reading ability effectively, it is quite signification to understand the reading process. Reading is an individual process that takes place inside readers mind in order to monitor, analyze, discuss and modify a classroom learning conditions. Reading is not only between reader and the text; instead reading is a more complex activity that includes different skills. Reading is a constructive process that uses the students Metacognitive strategies to build understanding of the text. Metacognitive strategies are sequential process that one uses to control cognitive activities and ensure a cognitive goal.

Flavell (1976) defines Metacognitive as one's knowledge concerning one's own cognitive processes. Baird (1990) uses ideas to provide formulation, " Metacognition refers to the knowledge, awareness and control of one's own learning". Metacognitive development is described as a development in one's Metacognitive abilities i.e. the move to grater knowledge, awareness and control of one's learning. One of the most vital skills that a person has to acquire in his life is reading. Reading can be seen as an interactive process between a reader and a text. In this reader interacts dynamically with the text to elicit, the meaning and various kinds of knowledge is being used. Readers have to use a flexible repertoire of strategies and cues to comprehend text and to solve problems with unfamiliar structure and vocabulary.

\section{Objectives of the study}

$>$ To examine and analyze the reading comprehension of learners

$>$ To compare the mean scores of reading comprehension of male and female

$>$ To compare the mean scores of Metacognitive strategy of male and female

\section{Hypothesis}

$>$ There will be a significant difference in the mean scores of Reading comprehension of male and female

$>$ There will be a significant difference in the mean scores of Metacognitive strategy of male and female in reading academic text

$>$ There will be a significant difference in the mean scores of Metacognitive Reading strategy with respect to gender

\section{Literature Review}

In research carried out by Degar (2002) on Reading Comprehension, the outcome was that the students Metacognitive skills are also competent readers. Weir (1998) express that the good readers use various sorts of metacognitive strategies in order to assure that they have achieve better reading. More recent research models have conceived reading as an interactive cognitive process in which readers interact with the text using their prior knowledge and cultural background (Carrell 1998). Thorn hill \& Joshi (2007) have tired to find out the impact of multiple cognitive strategies teaching on reading comprehension and vocabulary of the students. As an outcome for that research, it has been found out thatthe cognitive strategies have boosting impact on the reading comprehension, vocabulary and academic achievements of the students. Rout man (2003) defines Reading comprehension strategies as " tool or plans for facilitating and extending comprehension" (In Hardebecek 2006).

Researchers found out that Metacognitive reading strategies usage develops students reading comprehension level (Eiler and Pinkley 2006), According to these researchers, npt only using strategies increase the academic success but also successful students use strategies while reading. As a result of this, it is critical for college students to use reading comprehension strategies while reading academic materials for an effective learning. Reading comprehension can be defined as constructing a mental representation of textual information and its interpretation (Van Den Broek \& Kremer 2000). The present study is intended to fill the gap by reporting on the study in which to compare the metacognitive strategies and reading comprehension of Tertiary Level learners of English. 


\section{Methodology}

\section{Purpose of the study}

The purpose of the study was to identify Metacognitive strategies that the learners use while they are reading the academic text and examine these strategies.

\section{Participants}

Participants were twenty Tertiary Level learners in English of Bharathiar University College, Valparai. The study is to investigate the effectiveness of Metacognitive Strategy on Reading Comprehension to a group of Tertiary Level learners in English.

\section{Design}

A Metacognitive strategies questionnaire based on their reading was used to determine their cognitive abilities. To study to what extend the Tertiary Level learners use reading strategies. A questionnaire was developed and administrated to the students. More specifically, the questionnaire contains a list of twenty statements with respect to the use of strategies before, while and after reading. This research is a quantitative and the findings are based from the responses given by the respondents. The study is to identify the Metacognitive reading strategies of students in reading text. The data derived through questions, are answered by the respondents. Students were given twenty minutes to answer twenty questions. The respondents used their cognitive abilities to answer the questions. Learners performance in reading comprehension was measured with metacognitive strategy questionnaire. Participants were assessed in reading with the main focus o their prior knowledge. The data collected were analyzed using statistical analysis.

\section{Analysis}

There is a significant difference between the mean score of Tertiary level English learners towards reading text with respect to Gender. Source of variance and Reading comprehension measures were tested for significant difference between Gender using t-test

Table 1: summary of t-value of Reading comprehension

\begin{tabular}{|l|l|l|l|l|l|}
\hline $\begin{array}{l}\text { Source of } \\
\text { variance }\end{array}$ & $\mathrm{N}$ & Mean & SD & $\begin{array}{l}\text { Calculated } \\
\text { t-value }\end{array}$ & Result \\
\hline Male & 10 & 6.62 & 0.274 & -6.058 & *significant \\
Female & 10 & 7.55 & 0.400 & & \\
\hline
\end{tabular}

*significant at 0.05 level

\section{Interpretation}

Since the calculated t-value is (-6.058) greater than the table value (1.734) at 0.05 level of significance with degree of freedom $=18$. It shows that the mean scores of reading comprehension of female differ significant difference in mean scores of reading comprehension of male and female is rejected. Further mean scores of female is 7.55 which is significantly higher than that of male, whose mean scores of reading comprehension is 6.62 , it may therefore be said that female were found to have significantly higher reading comprehension than male. Therefore null hypothesis is rejected.

\section{Findings}

The present findings suggest that there is no significant difference in mean scores of Metacognitive strategies in reading comprehension. 


\section{Conclusion}

The outcome of this research shows the importance of improving metacognitive reading strategies while reading text among the English Tertiary level learners. The data reveals that reading strategies are directed towards comprehension could be developed through Metacognitive strategies. This study indicates that reader identifies problems and applies strategies to solve those problems. The result shows that there is no significant difference in mean scores of Metacognitive strategies in reading comprehension.

\section{Reference}

Baird, J.R (1990): Metacognition, purposeful inquiry and conceptual change

Carrell, P.L (1989): Metacognitive awareness and second language reading. Modern Language Journal 73,12-134

Flavell, J.H (1979): Metacognition and cognitive Monitoring. American Psychologist, 34 (10), 906911. 